\title{
ESTETIKA DALAM KONTEKS PENDIDIKAN SENI
}

\section{Sunarto ${ }^{\bowtie}$}

Prodi Pendidikan Sendratasik, Fakultas Bahasa dan Sastra, Universitas Negeri Semarang Jawa Tengah Indonesia

\section{Info Artikel \\ Abstract}

Sejarah Artikel:

Diterima Januari 2017

Disetujui April 2017

Dipublikasikan Juni 2017

\section{Keywords:}

Aesthetic Building,

Contemporary Art, Art

Education
The core of art is aesthetics, then art education is actually aesthetic education. Aesthetics itself is like a building, it has: roof, wall and hallway (foundation). As a roof, aesthetics give the spirit of art; The aesthetic wall gives themes and contents of art creation, and as aesthetic hall is the goal and background of art creation. Aesthetics are built on ideas, ideas and the purpose of creating works of art According to the results of research on the Art of Public Space in Yogyakarta (2015) shows that the aesthetic building of artwork has moved from the position, from the work to the connoisseur. The move is the latest (Contemporary) art phenomenon, resulting from the thinking of teenagers' paralogism and antihistorianism. This antagonistic, recent development is not anticipated by the learning of Arts Education in public schools.

\begin{abstract}
Abstrak
Inti seni adalah estetika, maka pendidikan seni sebenarnya adalah pendidikan estetika. Estetika sendiri digambarkan seperti bangunan, mempunyai: atap, dinding dan selasar (foundation). Sebagai atap, estetika memberi ruh karya seni; dinding estetika memberi tema dan isi penciptaan seni, dan sebagai selasar estetika merupakan tujuan dan latar belakang penciptaan seni. Estetika dibangun berdasarkan ide, gagasan serta tujuan penciptaan karya seni. Menurut hasil penelitian tentang Seni Rupa Ruang Publik di Yogyakarta (2015) menunjukkan bahwa bangunan estetika karya seni telah berpindah kedudukan, dari karya kepada penikmat. Perpindahan tersebut merupakan fenomena seni terkini (Kontemporer), yang dihasilkan dari pemikiran paralogisme dan antihistorianisme para remaja. Hal antagonis, perkembangan mutakhir ini tidak diantisipasi oleh pembelajaran Pendidikan Seni di sekolah umum.
\end{abstract}

(C) 2017 Universitas Muria Kudus 


\section{PENDAHULUAN}

Seni dan estetika bagaikan kepingan mata uung, seni merupakan unsur ekstrinksik yang dijadikan objek material dan estetika merupakan nilai instrinksik sebagai kajian formalnya. Keduanya memberikan harga suatu penciptaan dan sekaligus nilai sebuah karya. Jika 'seni' (karya) mampu mewadahi ide dan keindahan, maka estetika sebagai 'nilai' memberi kekuatan berupa ruh sehingga karya seni mampu menggugah imajinasi orang yang menikmatinya. Nilai sendiri bergantung kepada 'pengetahuan' orang yang menikmati (Driyarkara, 1969); seperti orang kaya diminta menghargai 'satu dollar', jumlah itu dianggap tidak berarti. Hal ini berbeda dengan orang miskin, 'satu dollar' baginya dapat mencukupi hidupnya.

Sebagai kota seni, Yogyakarta masih mempertahankan seni Klasik sebagai status quo seni; kesenian ini dianggap mempunyai kedudukan tinggi maka disebut sebagai karya adiluhung. Analog dengan masalah tersebut, hasil penelitian tentang fenomena seni ruang publik di Yogyakarta "Seni Rupa Ruang Publik Yogyakarta Relevansinya Terhadap Pengembangan Pendidikan Seni di Indonesia" (Hajar Pamadhi, 2015) menunjukkan perubahan visi terhadap 'nilai estetik'. Estetika Seni Rupa Ruang Publik (SRP) di Yogyakarta mengindikasikan bahwa: 1) terjadi perubahan pada tingkat dasar pola penciptaan karya seni; seni terpadu dalam satu bentuk kesenian (kolaboratif) antara seni rupa, seni tari dan seni musik maupun seni drama; 2) terjadi perubahan prinsip estetika, dari estetika atas menuju estetika bawah berbasis seni pop dengan dukungan seni urban; 3) terjadi redefinisi subjek estetika dan seni: dahulu karya seni memunculkan estetika dan prinsip penciptaan dengan jelas berada pada karya seni (Asikin Hasan. [ed.],. 2001). Dalam era posmodern ini terdapat kecenderungan berpindahnya estetika dari karya menuju ketergantungan penonton/penikmat seni (analog dengan pendapat Greg. Soetomo, 2003; Bagong Suyanto dan Khusna Amal [ed.], 2010). Temuan hasil penelitian yang lain adalah terjadinya perubahan cara mahami, produksi-reproduksi karya seni, dan objektivasi dan objektivikasi estetika.

'Bangunan estetika' merupakan istilah kiasan; penggambaran sebuah bangunan yang mempunyai dasar atau selasar, dinding dan atap. Makna estetika sebagai selasar seni adalah keindahan sebagai hasil objektivikasi dilihat dari pandangan epistemologi. Makna selasar estetika adalah dasar objektivikasi suatu pandangan seseorang terhadap estetika sebagai objek penciptaan karya seni, sebagai pandangan ontologi. Pandangan ini menjelaskan bahwa estetika berfungsi sebagai ruh karya seni karena keindahan suatu karya mampu diterjemahkan dan dikeluarkan dari sarang khayalan seseorang. Estetika dapat diselesaikan bersamaan dengan munculnya ide, gagagsan dan pengetahuan yang telah disimpan dalam memori otaknya. Sedangkan selasar merupakan titik besaran untuk memunculkan ujud, bentuk terhadap imajinasi seorang perupa (peseni) dalam usaha menggambarkan keutuhan karya seni. Selanjutnya, jika bangunan estetika ini dijadikan pendekatan pembelajaran seni di sekolah umum (non kejuruan) maka estetika merupakan tujuan akhir pembelajaran seni. Seni menjadi metoda pemerolehan estetika sebuah karya seni, estetika sebagai keindahan dapat diuraikan menjadi 5 pilihan (Abdulhadi W.M. 1998. Majalah Horison XXXIII: 19), yaitu:

1. Keindahan alam, yaitu keindahan yang absolute pemberian dari sang pencipta dunia.

2. Keindahan indrawi dan sensual, yaitu yang ditangkap oleh pancaindra manusia secara spontan yang berkaitan dengan kesukaan dan dikembangkan melalui kesenangan (hedonity); seperti kesukaan terhadap kecantikan susunan bunga-bunga yang berwarna.

3. Keindahan (aqliyah) merupakan pemahaman indah setelah mempertimbangkan asas keberadaannya.

4. Keindahan ruhaniyah (irfani) berkaitan dengan akhlak dan adanya pengetahuan tentang hakikat segala sesuatu pada diri seseorang atau karya seni, sastra dan keilmuan.

5. Keindahan Ilahiyah atau transedental.

Urutan ini juga dapat digunakan nuntuk menjelaskan langkah pembelajaran estetika pada proses berseni, mulai objektivikasi menuju proses subjektivikasi, estetika diinterpretasi dan divisualisasikan. Keindahan alam sebagai kausa prima ini menghadirkan pengetahuan. Pada waktu orang mengobjektivikasi keindahan alam (yang ada) terjadi proses belajar, melalui pemahaman inderawi pengetahuan tersusun. Instrumen utama objektivikasi rupa adalah mata; objekitivikasi ini merupakan proses mengubah menjadi elemen dan partikel ide menjadi bentuk imajiner. Proses ini dipengaruhi oleh kesenangan (hedonity) agar menemukan dan menentukan pilihannya.

Terbentuknya bangunan estetika ini disebabkan oleh: 1) visi seseorang dalam 
mengobjektivikasi; 2) pengetahuan seseorang dalam mengobjektivikasi dan menginterpretasi; 3) mempunyai kemampuan (keterampilan) berkarya seni; dan 4) mengubah partikel ide menjadi subjek dalam berkarya seni. Perjalanan estetika pada suatu objek menuju subjek dalam karya seni ini bergantung kepada kemampuan dan pengetahuan yang dipunyai oleh seseorang. Proses ini sangat halus dan bersifat imajiner, maka disebut sebagai seni halus dan/atau seni murni.

Dikatakan sebagai seni halus, karena bersifat pemikiran dan perasaan. lstilah itu muncul kemudian disebut seni murni karena ungkapan estetika seseorang bersifat 'nonkomersial' dan mengedepankan prinsip ekspresi bebas. Pengertian ekspresi bebas adalah ungkapan imajinasi tentang pikiran, perasaan dan gagasan seseorang yang diungkapkan secara bebas berdasarkan interpretasinya. Situasi ini mirip dengan seorang anak yang sedang berkarya seni. Seorang anak melakukan objektivikasi, interpretasi dan visualisasi menjadi karya seni. Kegiatan anak ini khas, dan tidak seluruhnya mirip dengan orang tua; proses subjektivikasi banyak dipengaruhi oleh sifat ego anak yang menguatkan ciri lukisan anak.
Proses mengeluarkan estetika dari sarang ide menuju pelepasan (ekspresi jiwa). Artinya, estetika yang telah dinyatakan cukup, siap untuk direpresentasikan oleh perupa disalurkan sesuai dengan kekuatan yang dipunyai. Di dalamnya termasuk usaha mengristalkan bentuk estetika dan menentukan pilihan warna yang sudah diinterpretasikan. Peristiwa ini bersifat abstrak berdasarkan pengalaman praktek laboratotium seni pada seseorang.

Ketika objektivikasi ini berjalan, terjadilah kegiatan jiwa manusia yang bersahutan untuk memperoleh kedudukan pertama dalam laku tersebut. Sigmund Freud menjelaskan, terdapat tiga domain yang saling berebutan mencari kedudukan: id, ego, dan superego; ketiganya berebut memberi kecerahan. Proses id adalah proses nafsu (nafs) untuk menguasai pikiran; pikiran dipermainkan dengan nafsu yang berasal dari 'rasa'. Rasa kemudian mempermainkan gagagsan seseorang untuk menggunakan akal maupun non-akal membongkar struktur $i d$ di atas (ego). Proses ini memanfaatkan pengetahuan yang disimpan untuk mewujudkan bentuk imajiner yang mampu mengembangkan kejelasan dan pencerahan dalam area superego.

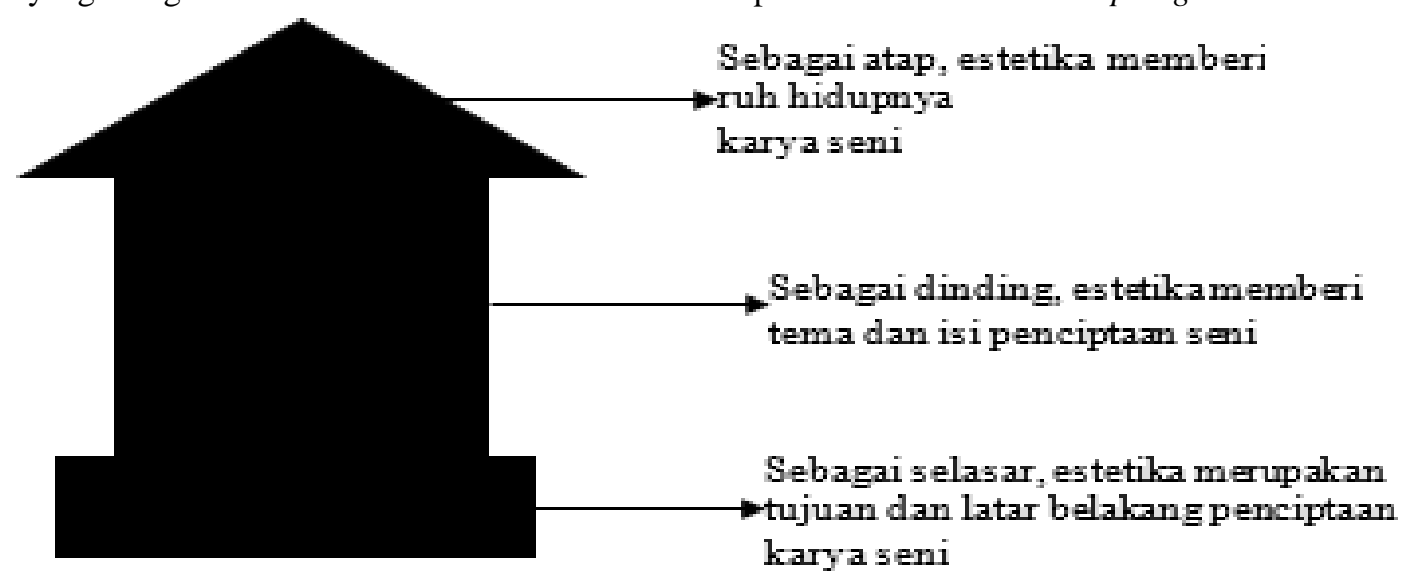

Gambar 1: Bangunan Estetika dalam Penciptaan Karya Seni

\section{Objektivikasi Estetika}

Berbicara estetika dalam apresiasi seni dapat dikaji dari proses pemilihan objek yang dijadikan subjek karya seni: 1) Proses mengamati termasuk di dalamnya adalah memahami terdapatnya estetika pada suatu objek. Perilaku sensual untuk menggugah hasrat terbesar manusia agar tersusun menjadi emosi; 2) Proses menentukan estetika pada suatu objek sasaran yang dipilih berdasarkan pertimbangan, hal ini akan menyebabkan proses aqliyah menemukan posisi objek semakin jelas; 3)
Jika digambarkan sebagai bangun segiempat; ide yang berupa titik besaran ini menjadi sumber terbentuknya segi empat atau bangun yang lain. Dari titik besaran terbayangkan menjadi garis, dari garis terbentuknua bangun segi-empat yang dibayangkan. Akhirnya, susunan titik dan garis menjadi lebih realistik sebagai permulaan bentuk. Proses halus ini dapat dimanfaatkan oleh seorang guru mengajarkan cara mengobjektivikasi dan memotivasi untuk dijadikan subjek suatu karya seni. Guru dapat melakukan pengajaran seni dengan meminta 
siswa melihat dan mengamati atau merasakan objek fisik maupun system yang ada di lingkungannya. Motivasi dilanjutkan dengan memberi gambaran bentuk (imajinasi) sebagai picture's thinking. Gambaran pikiran divisualkan melalui pengalaman keterampilan teknis. Kesenian yang dihasilkan seorang siswa dalam menciptakan karya seni merupakan proses lengkap dari gambaran di atas.

Berangkat dari kedudukan dan pengertian estetika terhadap seni, maka pembelajaran estetika terdapat 3 tahapan pembinaan, yaitu: 1) objektivasi dan objektivikasi melalui proses mengamati estetika sebuah objek dengan berujung akhir adalah memahami estetika suatu objek; 2) memelihara estetika, dalam arti memasukkan hasil objektivikasi ke dalam memori dalam proses interpretasi, konseptualisasi maupun representasi; 3) visualisasi setelah melalui interpretasi.

Proses ini semua menjadi langkah pendidikan berkesenian dapat digambarkan sebagai berikut:

1. Objektivasi adalah pengambilan fokus suatu objek; langkah ini dipengaruhi oleh interest pribadi, sehingga bersifat individual. Objektivikasi adalah usaha mengambil fokus suatu objek keindahan menjadi objektif (lebih dipandang umum ).

2. Memelihara estetika hasil eksplorasi terhadap suatu karya seni. Artinya, memelihara adalah kegiatan memasukkan ide estetika ke dalam memori melalui proses pertimbangan dan menglasifikasikan secara otomatis berdasarkan kebutuhan. Proses alami ini jika dilatih terus menerus akan menemukan pola-pola tertentu dan cepat diproses menjadi prinsip penciptaan serta materi dan ide terus berkembang. Pengajaran seni kepada siswa diarahkan kepada kemampuan dan keterampilan mengubah estetika 'imajinasi' menjadi estetika visual. Seorang guru memberikan insipirasi munculnya bentuk yang ada dalam alam pikiran siswa.

3. Memisualisasikan hasil interpretasi terhadap objek dan kemudian disusun menjadi subjek karya seni ini memerlukan pengetahuan yang luas. Dari sinilah Goldberg (1997:17) menjelaskan berseni merupakan kegiatan ilmiah. Seorang guru memotivasi pikiran siswa mengeluarkan 'ide' dan 'gagasan' yang disimpan dalam pengetahuan tersebut.

Objektivikasi dalam penciptaan karya seni mengalami perkembangan instrument objektivikasi (evolutionsm); dari pra-plato, Plato, sampai dengan Danto pemahaman terhadap keindahan mengalami perkembangan. Pra-plato mengidentivikasi indah dari teori mimesis, keindahan suatu objek terletak pada kemampuan seseorang melakukan imitasi. Imitasi merupakan proses pemindahan objek melalui interpretasi objek sehingga menemukan kesamaan ciri tanpa cacat (Bagoes P. Wiryomartono, 2011). Ide mimesis berjalan sangat lama, bahkan sampai sekarang pemahaman tersebut masih berlaku. Kegiatan imitasi terhadap 'alami' bukan mengopi bentuk tetapi merubah media dengan lebih dahulu melakukan interpretasi, sehingga objek hanya berperan sebagai penggugah ide peniruan. Proses imitasi yang sebelumnya berlaku melalui ideografi terlebih dahulu. Sederetan ide-ide dibuat ikon berbentuk simbol budaya dengan makna, kemudian dikemas ulang menjadi bentuk utuh berupa gambaran objek. Sebagai contoh, tradisi biomorphomisme; mereka menciptakan gambar dari ideogratis terhadap fungsi dan jabatan dewa, kemudian property, asesori serta tanda khas kedewaan dilengkapi dengan tatacara dan pranata sistemnya sehingga terwujud figur dewa. Dewa merupakan idealisme manusia (dewa) dengan atribut, property dewa serta ketugasannya. Munculnya imajinasi 'dewa' dari ikon-ikon serta ideografi yang diberikan oleh agama atau kepercayaannya. Para pematung masa 'biomorphisme' ini mampu berimajinasi bentuk berdasarkan ikonografi.

Imanuel Kant (1956:68) mulai mengembangkan gagagsan baru tentang estetika; gagasan ini dipengaruhi oleh ilmu pengetahuan alam. sehingga buku yang mengupas tentang objek berasal dari pengetahuan visualnya (alaminya). Instrument pokok dalam mengidentifikasi objek (objektivikasi) berasal dari mata, dari mata dapat diidentifikasi bentuk-bentuk yang dapat digolongkan serta dianalisis kondisinya. Keindahan pun juga berangkat dari pikiran logis terhadap objek yang realistis. Hadirlah prinsip alami dalam mengobjektivikasi keindahan (Krtitik Rasio Murni, 1786); namun ide ini segera diralat sendiri dengan memantapkan objektivikasi berasal dari "akal budi praktis" (Kritik Budi Praktis). Budi adalah jawaban lain dari akal, karena akal sudah tidak mampu menjawab pertanyaan munculnya suatu ide. Segala sesuatu yang ada ternyata oleh orang lain dianggap 'ada' dan yang tidak dapat dipecahkan melalui akal. Perilaku seseorang untuk menemukan solusi yang tidak terdapat pada akal (rasio) ini disebut dengan budi. Budi lebih 
realistis berasal dari kehidupan dan pengalaman sosialnya. Proses sosial ini budi memegang peranan penting, karena memunculkan solusi pemecahan masalah yang tidak terkait dengan akal. Instrumen budi menjadi lebih luwes, karena rasa dapat digunakan untuk memecahkan permasalahan. Contoh: 'objek lingkungan sosial'.

$$
\begin{aligned}
& \text { Seorang pencipta seni } \\
& \text { terkooptasi objektivikasi pada } \\
& \text { 'peristiwa sosial', maka } \\
& \text { instrument rasa yang bergerak } \\
& \text { terlebih dahulu, baru setelah } \\
& \text { terbentuk suatu pengetahuan } \\
& \text { tentang 'sosial' dari } \\
& \text { permasalahan tersebut akal } \\
& \text { bergerak untuk mewujudkan } \\
& \text { budi yang telah membangun } \\
& \text { imajinasinya. Proses ini lebih } \\
& \text { berada pada medan 'budi atau } \\
& \text { rasa'. Sebuah karya seni } \\
& \text { terkini yang ada di ruang } \\
& \text { publik Yogyakarta seperti } \\
& \text { 'seni instalasi' dan 'seni } \\
& \text { patung' kemerlukan } \\
& \text { interpretasi ketika akan } \\
& \text { mengapresiasinya. }
\end{aligned}
$$

Kemudian Baumgarten (Collingwood, 1983) mempunyai rumus baru. Berangkat dari 'budi' tersebut ternyata sebuah karya seni merupakan proses halus yang memerlukan interprertasi khusus (Wiryomartono, 2011). Keindahan suatu karya seni menjadi subjektif dan perlu diangkat melalui rasa yang berkait dengan budi, akhirnya muncullah prinsip 'nilai'. Nilai merupakan area yang mengundang 'pikiran; dan yang lain 'perasaan'. Seseorang yang sedang melakukan interpretasi terhadap objek, menurut Baumgarten adalah proses halus yang sangat subjektif. Pikiran dan perasaan sulit dideteksi, oleh karenanya disarankan agar proses halus ini dilihat dari kejadian 'hasil karya seni' terhadap sejarah penciptaannya.

Secara ringkas, perkembangan objektivikasi estetika telah melalui proses berbagai pertimbangan, mulai dari mimesis, interpretasi seperti ilmu alam, ilmu sosial. Objektivikasi ini disarankan menggunakan instrumen variatif, misalnya Plato menyarankan dari mata menuju alam pikiran yang nyata. Kemudian, imajinasi dirangsang untuk menghasilkan picture's painting dan pengetahuan yang kanonik. Prinsip kanonik seiring dengan berpikir akademis, idealisme dan positivisme. Kondisi ini diperkuat ketika Levi Strauss (Ashadi Kusuma Djaya, 2012) mengemukakan teori 'strukturalisme', terbentuknya karya seni merupakan pemusatan pikiran secara struktural. Kesenian yang dihasilkan dapat dibayangkan sebelumnya. Kesenian Klasik merupakan dampak (impact) dari berpikir rasional atau ilmiah agar sebuah karya seni harus tersusun sebagai kekuatan pikiran, seperti pendapat Imanuel Kant dalam kritik rasio murni.

Gerakan tersebut segera dipatahkan oleh 'dekonstruktivisme' yang diangkat oleh Jacques Derrida. Inti dekonstruksi adalah mempertanyakan 'metafisika kehadiran', yaitu mempertanyakan suatu arti tunggal (Al-Fayyadl, 2005:36, Norris, 2003:17; Dadan Rusmana, 2014). Jawaban terhadap suatu masalah tidak seharusnya tunggal karena akan menggugah kreativitas. Prinsip dekonstruksi sebenarnya untuk bahasa; arti suatu kata ternyata berkembang menurut kebutuhan, namun bagi seorang yang berpikir 'kuasa tunggal' ditolak, oleh karenanya dapat hadir lebih dari satu jawaban.

Contoh: bagaimana hasilnya jika besi dipanasi? Hasil percobaan nyata (eksperimentasi) terdapat beberapa jawaban: memuai, melengkung, meleleh. Semua jawaban dianggap benar: maka karya senipun harus memopunyai varuiasi terhadap objektivikasi estetika.

Estetika yang dibangun berdasarkan rasionalitas ini sebagai penguatan untuk kaum hegemonis. Kelompok hegemoni ini dianggap sebagai penguasa dalam 'politik, ekonomi, agama, dan budaya' (Hajar Pamadhi, 2015). Dalam proses sosial 'kekuasaan' sudah harus diterjemahkan berbeda, tidak untuk hegemoni, melainkan berdasarkan kondisi nyata (eksperimentasi) bukan idealisme. Svasek (2007:17) dikatakan:

It is important to realise that
evolutionist arguments were not
only deployed to create
distingtions between the civilised
Euoropean colonisers and the
civilisers and uncilivised non
Europian colonised, but were also
played out in gender politics and
in the context of intra-European
political processes.

Oleh Andi Warholl (1960) dinyatakan dengan 'seni pop' yang bertujuan untuk memperjuangkan seni rakyat, seni yang diciptakan rakyat tersebut mempunyai terminologi yang berbeda dengan seni 
sebelumnya. Seni merupakan ekspresi 'murni' seseorang untuk menyatakan pendapat berdasarkan pengalaman 'nyata' (reality). Konsepsi seni posmoderen Warholl ini menjadi terdepan dan meminta legitimasi estetika kerakyatan.

\section{Konsep Pendidikan Seni}

Bangunan estetika menjadi variatif bentuknya, walaupun strukturnya tetap. Di bawah ini merupakan gambaran fisik seni Kontemporer yang sudah tidak berbataskan lagi oleh sekat seni rupa, seni tari, seni musik; karya mereka seperti kolaborasi diantaranya. Hal ini terjadi karena sasarannya adalah estetika. Jika pada masa modernisme sekat itu kuat bahkan menjadi soliditas pengetahuan khas, maka perkembangan filsafat (cara berpikir kritis) remaja berada pada global maka seni bertumpu pada estetika. Estetika sebagai commonground ideologi seni-seni tadi menjadi titik nutfah bangun estetika. Dari pemahaman ini muncul gagasan ide pengembangan bentuk yang dipadukan dengan gerak, suara maupun cerita/tema.

Dalam skema tersebut digambarkan bahwa nilai (berupa estetika) merupakan titik sentral pengembangan ide penciptaan. Estetika sendiri bergantung kepada objektivikasi yang tersusun dari 3 konponen: selasar, dinding dan atap. Kesemuanya ini berjalan secara otomatis bagaikan jaringan cardiovasculair yang mengangkut dan memfasilitasi darah berputar untuk mewujudkan 'hidup' pikiran dan rasa dalam berkarya seni. Terbentuk sistem nilai tersebut berangkat dari habitus, pengetahuan yang tersimpan, serta interpretasi pada waktu objektivikasi. Proses ini tidak membedakan prinsip keterpisahan melainkan kesatuan berdasar prinsip penyusunan: komposisi, keseimbangan, nada, irama, tekanan (center of interest), warna maupun tekstur, pada karya: musik, tari, rupa maupun drama. Mereka digiring dengan tema terbangunlah ide penciptaan kary Proses simbiosis memberikan gambaran susunan berdasarkan kekuatan pengetahuan.

Siswa pada waktu menerima pelajaran sebaiknya memosisikan pada netral, yaitu menerima seni sebagai cara atau metode (techne) mengidentifikasi estetika suatu objek agar menampung ide (poesis). Secara otomatis terjadi peningkatan kemampuan melalui pelatihan sendiri maupun bersama guru. Proses apresiasi kemudian objektivikasi untuk menemukan titik terkuat pencerahan bentuk. Jika persoalan tersebut di atas dikaitkan dengan perkembangan seni mutakhir yaitu seni Kontemporer, estetika Kontemporer dihasilkan dari perenungan objek baik fisik maupun sistem kemasyarakatan hingga menyentuh gambaran titik tumpu estetika: gerak, suara, bentuk (rupa) maupun drama.

Berbicara seni Kontemporer; karya seni dianggap sesuatu yang baru dalam arti ide pemanfaatan ruang publik. Ruang dalam seni adalah jarak gagasan yang dapat diberi muatan pesan sehingga terjadi keterkaitan antara ide dengan kenyataan yang ada. Beberapa karya seni Kontemporer mencoba mengangkat teori mimesis Plato, yaitu memberikan apropriasi seni tradisi. Apropriasi diartikan bukan sebagai pengikut gerakan tradisi, melainkan sebagai usaha mencari legitimasi estetika. Seni Kontemporer didukung oleh urbanis mengangkat pola tradisi ke dalam rubrik urban. Dalam skema struktur seni yang berintikan estetika Kontemporer merupakan commonground dari nilai cabang seni yang lain.

Struktur estetika Kontemporer ini ternyata dekat dengan kegiatan siswa ketika sedang berkarya seni. Sebenarnya anak tidak mengerti maksud 'seni visua/seni tari, seni musik', yang dipentingkan adalah berkarya seni.

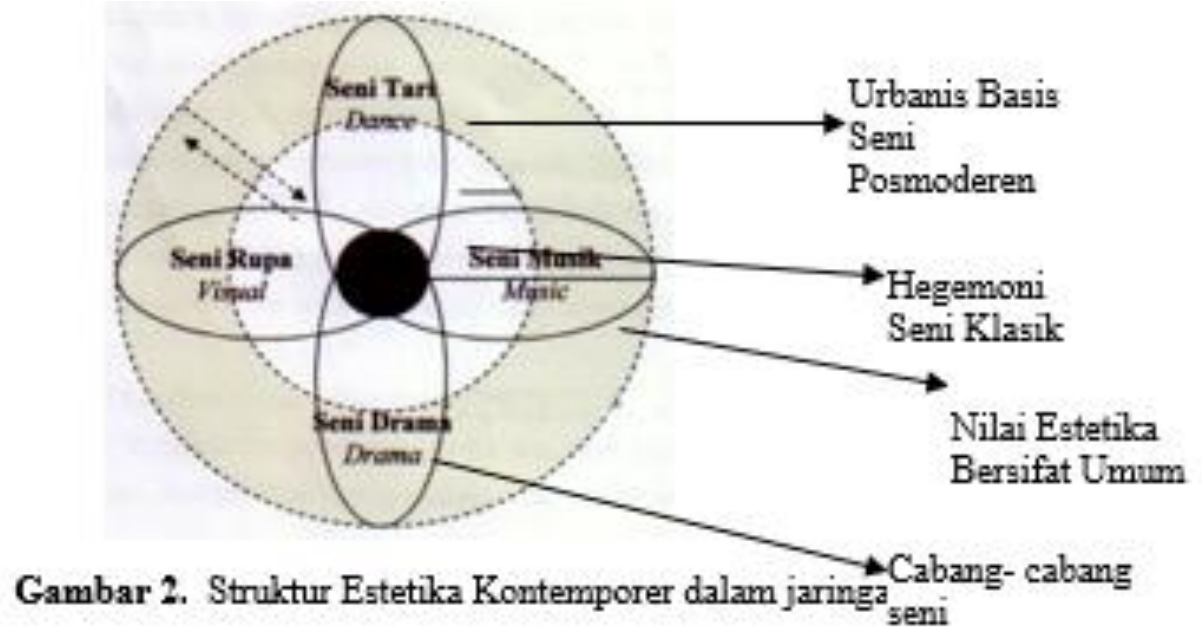


Mereka mencipta karya seni mulai dari gerakan bersahaja mengisi ide-ide yang diberi guru. Maka, Pendidikan Seni pada masa sekarang ini dapat mengambil keputusan dengan menyamakan dengan proses siswa berkarya. Pendidikan Seni menjadi alat untuk melatih kepekaan rasa melalui objektivikasi dan memelihara ide dengan sentuhan apresiasi yang diberikan oleh guru. Posisi ini siswa berada pada the owner sebuah penciptaan karya seni. Siswa menentukan pola, prinsip dan gerakannya sendiri agar mampu memberikan hasil yang sesuai dengan gagasan. Jika dirangkum, pendidikan seni bertujuan: 1) memfasilitasi siswa berekspresi bebas dengan memberikan kesempatan mengutarakan gagasan, imajinasi. Cara memfasilitasi adalah melatih keterampilan teknis berkarya; 2) Melatih sensibilitas melalui objektivikasi fisik, sistem dan nilai. Objektivikasi fisik, siswa dilatih melihat, merasakan dan menguatkan fokus masalah, objektivikasi sistem sosial dengan mengamati peristiwa dan merasakan keberadaan diri dalam proses sosial. Semua diungkapkan secara jujur untuk menemukan prinsip penciptaan; 3) Mengarahkan penciptaan berdasar habitus, dibangun dari kesempatan mengemukakan pendapat.

\section{Visi Kearifan Lokal dalam Pendidikan Seni}

Permasalahan selanjutnya, ketika seni telah menjadi sebuah disiplin (ilmu) dengan struktur khas masing-masing cabang seni akan memberikan gambaran berbeda terhadap sistem pemecahannya. Sebagai contoh: seni musik dengan terpecahnya instrumen dan vokalia mempunyai satuan sistem yang mulai berbeda. Demikian pula dengan seni rupa, yang semula sebagai seni visual (seni yang menggunakan instrumen penikmatan dengan mata) berkembang menjadi seni patung, seni grafis seni lukis dan kinetic art menjadi terpisah diantaranya. Sejarah mereka memberikan arah berbeda di antaranya. Perkembangan ini mengerucut dengan konsep seni adalah ilmu.

Kondisi terkini dengan kehadiran seni Kontemporer konsep seni yang terpisah menjadi satu kembali, seiring dengan prinsip integrasi. Seni sebagai refleksi sosial, maka dapat digunakan untuk kepentingan sosial. Kondisi ini mampu mengapresiasi kesenian sebelumnya, karena sifat berpikir kritis masyarakat Kontemporer didasari oleh pemikiran paralogisme. Para pendukung seni Kontemporer menerima kehadiran seni tradisi sebagai kesenian rakyat. Penelitian seni Kontemporer menghasilkan rumusan tentang perilaku masyarakat urbanis. Urbanis berasal dari kalangan rakyat atau non-borjuis, sehingga mampu mengangkat estetika seni rakyat sebagai basis penciptaan. Hal ini berbeda dengan seni modern yang telah menyatakan seni baku mutu (kanonik), sehingga unsur seni lain diapresiasi sebagai seni yang berada dalam dirinya. Apropriasi terhadap seni rakyat menjadikan posisi kesenian tradisional sebagai tema 'estetika rakyat atau kerakyatan'. Istilah estetika rakyat adalah estetika sebagai produk rakyat (secara politik berpikir pertentangan dengan pemerintah atau borjuis), sedangkan estetika kerakyatan adalah estetika pada seni kontemporer ditujukan untuk mengangkat rakyat sebagai objek dan subjek merepresentasi 'rakyat'.

Telah disepakati bahwa seni tradisi dimaksudkan adalah seni yang hadir dengan prinsip reproduksi makna; kesenian ini merupakan bagian dari tradisi budaya dilaksanakan oleh masyarakat pendukung. Seni tradisi dapat dikatakan berbasis kerakyatan, artinya seni dimiliki oleh rakyat sebagai modal presentasinya dalam kehidupan, seperti upacara, pergaulan maupun pranata sistem sosial (masyarakat setempat). Seni Kontemporer juga berbasis seni kerakyatan dalam arti yang berbeda; mereka ingin menyuarakan proses sosial dan produk sosial (masyarakat sekitar) maupun penderitaan rakyat dalam bentuk seni. Kedudukan yang berbeda ini seni Kontemporer berani mengungkapkan secara fulgar dengan laku mimesis, sebagian visi tradisi diangkat menjadi tema karya seni namun bukan sebagai pelaku tradisi masyarakat. Gagasan ini menjadi semakin marak ketika pola-pola tradisi dianggap mempunyai nilai keindahan. Sehingga seni tradisi mampu mengangkat imajinasi baru peseni Kontemporer.

Para perupa kontemporer lebih bebas memilih jenis estetika, mereka berangkat dari tradisi menuju modern atau pemikiran modern yang mengangkat 'tema kerakyatan' sebagai dasar penciptaan (Arvon Henry, 2010. Chernyshevsky, 1953: 52; Antariksa, 2005). Pertemuan ide tersebut menghasilkan kesenian yang khas dengan nilai yang satu, yaitu bertujuan mengangkat 'rakyat' (baik dalam proses sosial maupun produk sosial) masuk dalam lingkaran objektivikasi. Kapasitas pencarian nilai tradisi ke dalam visi modern dan sebaliknva pemikiran modern yang mampu mengangkat tradisi sebagai kekuatan dalam penciptaan dan berperilaku ini disebut dengan kearfian lokal. Prinsip kearfian lokal adalah kemampuan yang menunjukkan kapasitas berpikir, bekerja serta sistem yang berisikan tradisi serta modern yang terpadu berdasarkan 
Tabel 1. Pengajaran Seni dengan Bangun Estetika

\begin{tabular}{|c|c|c|}
\hline No & $\begin{array}{l}\text { Pengajaran Seni dengan } \\
\text { Bangun Estetika }\end{array}$ & Hasil \\
\hline 1. & Sebagai selasar & $\begin{array}{l}\text { - Memantapkan proses objektivikasi dengan } \\
\text { kemampuan memilih dan memilih objek secara } \\
\text { intens sebagai pegnayaan kemampuan } \\
\text { berimajinasi } \\
\text { - Kemampuan memahami posisi, prinsip } \\
\text { keindahan dalam objek dan diangkat sebagai } \\
\text { subjek melalui proses representasi }\end{array}$ \\
\hline 2. & Sebagai dinding & $\begin{array}{l}\text { - Estetika memberikan motivasi menghias seni } \\
\text { dengan tema-tema sosial dan berdampak } \\
\text { samping tumbuhnya nilai toleransi sosial } \\
\text { - Melatih penguatan penyusunan bentuk-bentuk } \\
\text { melalui perasaan indah yang dibangun } \\
\text { berdasarkan habitus seni }\end{array}$ \\
\hline 3. & Sebagai atap & 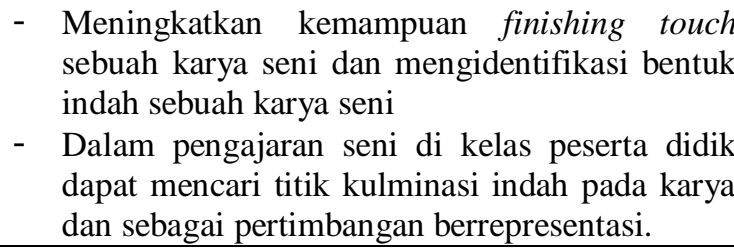 \\
\hline
\end{tabular}

kebutuhan masing-masing orang. Dari kebutuhan ini menghasilkan pemikiran paralogia pada urban, prinsip perbedaan dengan tujuan berkarya seni. Proses ini menjadikan urban mengapropriasi seni tradisi dan mengapresiasi kehadiran seni modern.

Mengemas pembelajaran nilai dalam kearifan lokal, adalah memasukkan “... keyakinan abadi (enduring belief) yang dipilih oleh seseorang atau sekelompok orang sebagai dasar untuk melakukan kegiatan tertentu (mode of conduct) atau sebagai tindakan (end state of existence) dan juga merupakan standar untuk melakukan penilaian, untuk menentukan pilihan, bersikap serta berargumentasi dengan individu lainnya mengenai suatu obyek." (Milton dan Rokeach dalam Robbins, 2009).

Beberapa pendapat di atas dapat disatukan dalam konstelasi pemahaman estetika dalam pendidikan seni sebagai suatu kekuatan menghidupkan perilaku indah. Nurturant effect pembelajaran estetika adalah memahami indah dalam bentuk fisik, sistem maupun nilai. Kondisi ini menyebabkan terbentuknya sistem dalam kehidupan seni maupun bersosial.

Dari uraian penjelasan di atas dapat digambarkan bahwa Pendidikan Seni yang berbasis pendidikan estetika mempunyai arah

\section{SIMPULAN}

Estetika dalam bangun Pendidikan Seni untuk sekolah umum mampu memberikan kerangka berobjektivikasi dan berepresentasi; hal ini sangat penting sebagai dasar pengembangan pribadi peserta didik dan usaha mengembangkan cita dan citra karya seni. pembelajaran seni pada hakikatnya adalah pembelajaran rasa indah, indah pada waktu mengobjektivikasi, indah dalam berimajinasi, dan indah dalam mengungkapkannya dalam pada seni, dampak ikutan, pendidikan estetika mempunyai peran sebagai pendidikan karakter terutama toleransi sosialnya. Pendidikan seni berbasis estetika tetap dilaksanakan sebagai pelatihan seni dengan mengapresiasi secara simultan karya seni.

\section{DAFTAR PUSTAKA}

Abdul Hadi W.M. 2004. Hermeneutika, estetika dan Religiusitas: Esai-esai Sastra Sufistik dan Seni Rupa. Yogyakarta: Mahatari.

Antariksa. 2005. Tuan Tanah Kawin Muda: Hubungan Seni Rupu-LEKRA 19501965. Yogyakarta: Yayasan Cemeti.

Arvon, Henry. 2010. Estetika Marxis. Diterjemahkan oleh Ikramullah. Yogyakarta: Resis Book,

Ashadi Kusuma Djaya. 2012. Teori-Teori Modernitas dan Globalisasi. Yogyakarta: Kreasi Wacana. 
Asikin Hasan (ed.). 2001, Dua Seni Rupa (Sepilihan tulisan Sanento Yuliman), Jakarta: Yayasan Kalam bekerjasama dengan Yayasan Adikarya IKAPI, Ford Foundation, dan Majalah Berita Mingguan Tempo.

Bagong Suyanto dan M. Khusna Amal, (ed.). 2010. Anatomi dan Perkembangan Teori Sosial, Aditya Media Publishing, Malang.

Bagoes P. Wiryomartono. 2011. Pijar-Pijar Penyingkap Rasa, Sebuah Wacana Seni dan Keindahan dari Plato sampai Derrida. Jakarta: Gramedia Pustaka Utama.

Chernyshevsky, N, G. 1953. Hubungan Estetik dengan Realitas. Diterjemahkan oleh Samanjaya. Jakarta: CV. Ultimus.

Colingwood, R.G. 1983. The Principles of Art. London: Oxford University Press.

Dadan Rusmana. 2014. Filsafat SemiotikaParadigma, Teori, dan Metode Interpretasi Tanda dari Semiotika Struktural hingga Dekonstruksi Praktis, Bandung: Pustaka Setia.

Driyarkara, N., 1969, Filsafat Manusia, (cetakan pertama), Penerbit Kanisius, Yogyakarta

Greg Soetomo. 2003. Krisis Seni Krisis Kesadaran, Yogyakarta: Kanisius.

Hajar Pamadhi. 2012. Pendidikan Seni: Hakikat, Kurikulum Pendidikan Seni, Habitus Seni dan Pengajaran Seni Untuk Anak. Yogyakarta: UNY Press.

Immanuel, Kant. 1956. Kritik Atas Akal Budi Praktis. Diterjemahkan Nurhadi, 2005), Pustaka Pelajar, Yogyakarta.

Muhammad Al-Fayyadl, 2005, Derrida, Yogyakarta: LKIS.

Norris, Christopher., 2003, Membongkar Teori Dekonstruksi Jacques Derrida, Diterjemahkan oleh Inyiak Ridwan Muzir. Yogyakarta: Ar-Ruzz Media.

Robbins, Sp., and Judge, T.A. 2009. Perilaku Organisasi. Jakarta: Salemba.
Svasek, Maruska. 2007. Anthrology, Art Cultural Production. London: Pluto Press. 